\title{
Congressional Underappropriation for Civil Juries: Responding to the Attack on a Constitutional Guarantee
}

\author{
Jonathan Bunge $\dagger$
}

Separation of powers struggles often play themselves out against a backdrop of great historic events: Lincoln's suspension of habeaus corpus during the Civil War, for example, or Truman's seizure of the steel mills as part of his effort to save an ally of redscare America from the Chinese. At these times, propelled by the exigency of the circumstances, public officials test limits on their power that they might otherwise respect. Recently, however, a separation of powers conflict pitted two branches of the federal government against each other through one of the most routine tasks known to modern government: ordering the national budget.

Congress appropriated only $\$ 43.4$ million, rather than the originally requested $\$ 46.2$ million, for the payment of jury fees and juror expenses in fiscal year 1986. ${ }^{1}$ Because of the difference between the requested and the granted appropriations, it appeared in early June of 1986 that the funds available to pay jurors would be exhausted before the end of the fiscal year on September 30. If the funds eventually were exhausted, the Anti-Deficiency Act, ${ }^{2}$ which bars United States officers and employees from obligating the federal government to make payment for which no money has been appropriated, and 28 U.S.C. $\$ 1871$, which provides for the payment of jury fees and expenses, would arguably combine to prohibit judges from empaneling any juries until Congress appropriated additional money.

On June 12, 1986, the Administrative Office of the United States Courts, at the direction of the Executive Committee of the Judicial Conference of the United States, issued a memorandum stating that because Congress failed to appropriate sufficient funds for juror payment, "civil jury trials will have to be suspended on June 16 through the end of the fiscal year (September 30) ...

† A.B. 1984, Princeton University; J.D. Candidate 1988, The University of Chicago.

1 Departments of Commerce, Justice and State, the Judiciary, and Related Agencies Appropriation Act, Pub.L.No. 99-180, 99 Stat. 1136, 1154 (1985).

$=31$ U.S.C. $\S 1341$ (1982). 
[T] Je Judicial Conference has directed that you empanel no new civil juries from June 16 forward . . . [T] [Tis suspension . . . must continue in effect until we inform you that sufficient funds have been made available." While juror expenses were not exhausted at the time of the memorandum, the Administrative Office issued its directive to ensure that federal courts would have sufficient funds to empanel criminal juries. ${ }^{4}$

In two cases, Armster v. United States ${ }^{5}$ and Hobson v. Bren$n a n,{ }^{\bullet}$ civil litigants successfully sought to have juries empaneled after June 16, despite the June 12 Administrative Office memorandum. While influenced by the litigants' seventh amendment right to a jury trial in civil cases, the Hobson court rested its decision primarily upon statutory grounds, holding that since funds for juror expenses were not yet exhausted, neither the Anti-Deficiency Act nor the Administrative Office memorandum prohibited judges from empaneling jurors in civil cases where a suspension would create undue hardship. ${ }^{7}$ The Armster court, however, bypassed the statutory questions on the grounds that they had not been adequately briefed, and held that the three month suspension of civil jury trials violated the litigants' seventh amendment right to a jury trial. ${ }^{8}$

Since the money for juror expenses never actually ran out, the Armster court never had to consider whether courts could compel the federal government to pay jurors in the absence of funds appropriated by Congress for that purpose. Nonetheless, Armster's holding that a three month suspension of jury trials would be unconstitutional suggests that if the money had in fact run out, the courts still would be required to empanel juries, thereby obligating Congress to make the necessary payments.

If Congress cuts civil jury trial funding again, how should the federal courts, or a litigant denied a civil jury trial, respond? ${ }^{\ominus}$ Part

${ }^{3}$ L. Robert Mecham, Memorandum to All United States District Judges, Subject: Suspension of Civil Jury Trials (June 12, 1986), quoted in Armster v. United States, 792 F.2d 1423, 1425 (9th Cir. 1986). The Administrative Office of the United States Courts and the Executive Committee of the Judicial Conference of the United States are part of the judicial branch.

Id. at 1426.

s 792 F.2d 1423.

637 F.Supp. 173 (D.D.C. 1986).

7 Id. at 175.

792 F.2d at 1430 .

- It is likely that Congress will decide to cut funds for civil jury trials again since the Gramm-Rudman-Hollings Act motivates Congress to trim the national budget wherever possible. Balanced Budget and Emergency Deficit Control Act of 1985, Pub.L.No. 99-177, 
I of this comment considers and rejects the possibility, suggested by some state courts, that the judiciary has a self-executing power to appropriate funds to satisfy its own budgetary needs. Part II argues that the seventh amendment obliges Congress to pay necessary juror expenses as part of the government's general duty to provide litigants in federal court with civil juries. Part II also argues that a federal court faced with a civil case where a litigant has been denied a jury has the authority to enforce the seventh amendment's affirmative obligation. Part III demonstrates that federal courts have standards by which they can evaluate whether a civil jury trial delay should be treated like a civil jury trial denial.

\section{The State Court Approach to Legislative Underfunding: The Inherent Power of the Courts to Appropriate}

A. The Inherent Power Doctrine as Applied and Defined by State Courts

When faced with inadequate funding from the legislative branch, some state courts have argued that they possess an inherent power to set their own budgets and to order the appropriation of public funds to satisfy those budgets. ${ }^{10}$ State courts applying this principle generally have justified it through two similar arguments. First, courts have argued that the very existence of the judiciary requires that it have the ability to appropriate funds necessary for its survival. Second, courts have argued that failure to recognize such inherent power would jeopardize the state constitutions' separation of powers by making state courts fiscally dependent upon the legislature.

In asserting that the very existence of the judiciary requires a power to appropriate public funds, state judges have relied on state constitutions that both create general jurisdiction state courts and also guarantee access to those courts. Because their

1985 U.S.Code Cong. and Admin. News (99 Stat.) 1037 (codified at 2 U.S.C. § 401).

${ }^{10}$ State court inherent power issues have arisen in other contexts as well. See, for example, Baten v. State, 101 So.2d 869, 875 (Fla.App. 1958) (court does not have inherent power to delay imposition of a two year criminal sentence for one year); In Re Pruitt, 249 Ga. 190, 288 S.E.2d 208, 210 (1982) (trial court has inherent power to punish for contempt but not to exceed limits imposed by the legislature for contempt penalties); In Interest of E.C., 130 Wis.2d 376, 387 N.W.2d 72, 77 (1986) (trial court lacks inherent power to order police department to expunge police records of juveniles); State v. Braunsdorf, 98 Wis.2d 569, 297 N.W.2d 808, 816 (1980) (trial courts lack inherent power to dismiss criminal cases with prejudice before jeopardy attaches); Jacobson v. Avestruz, 81 Wis.2d 240, 260 N.W.2d 267,270 (1977) (trial court has inherent power to assess costs of empaneling jury on parties who settled claim after counsels' opening statements). 
state constitutions are structured in this manner, these judges have contended that they must have the inherent power to ensure their courts' survival by appropriating money necessary for their courts' continued functioning. In O'Coins, Inc. v. Treasurer of County of Worcester, ${ }^{11}$ for example, the Massachusetts Supreme Judicial Court held that a lower court judge had the authority to bind his county contractually for the price of a tape recorder and four tapes needed by the judge in his courtroom. The O'Coins court reasoned that all Massachusetts judges have the inherent power to bind their local governments for "expenses reasonably necessary for the operation" of their courts. ${ }^{12}$ According to O'Coins, "[i]t would be illogical to interpret the Constitution as creating a judicial department with awesome powers over the life, liberty, and property of every citizen while, at the same time, denying to the judges authority to determine the basic needs of their courts as to equipment, facilities and supporting personnel."13

More commonly, state courts justify use of the inherent power doctrine to appropriate public funds by claiming that the inherent power doctrine is necessary to promote the state constitution's separation of powers. Without the inherent power doctrine, these courts argue, the separation of powers doctrine has no fundamental coherence: the legislative branch might conceivably destroy the judicial branch by inadequately funding the judiciary, or the legislature, through its ability to deny funding, might coerce the courts into passively affirming all of the legislature's actions.

In a leading inherent power case, Commonwealth ex rel. Carroll $v$. Tate ${ }^{14}$ for example, the judges of the Philadelphia common pleas court brought suit against the mayor of Philadelphia seeking funds for administration of the common pleas court in fiscal year 1970. The city had allotted the common pleas court five million dollars less than the judges had requested. The Pennsylvania Supreme Court held that the common pleas judges had the inherent power both to determine the amount necessary for the operation of the pleas court and to compel payment of that amount.

Tate argued that if the Pennsylvania courts did not have this inherent power, the legislature might destroy the state constitution's separation of powers by destroying the judiciary. "Unless the legislature can be compelled by the Courts to provide the money

11362 Mass. 507, 287 N.E.2d 608 (1972).

12287 N.E.2d at 611.

1s Id. at 612.

14442 Pa. 45, 274 A.2d 193 (1971). 
which is reasonably necessary for the proper functioning and administration of the Courts, our entire judicial system could be extirpated, and the legislature could make a mockery of our form of government with its three co-equal branches."15

Other courts advocating the inherent power doctrine have pointed to a second separation of powers concern: that the legislature might use its control over the judiciary's funds to influence the courts' judgments. In Carlson v. State, ${ }^{16}$ for example, a judge in Hammond, Indiana presented the city council with a budget for the operation of the city court which the council refused to pay. Holding that the local court had the power to set its budget, including salaries, the Indiana Supreme Court argued that "[o]ur sense of justice tells us that a court is not free if it is under financial pressure, whether it be from a city council or other legislative body, in the consideration of the rights of some individual who is affected by some alleged autocratic or unauthorized official action of such a body. One who controls the purse strings can control how tightly those purse strings are drawn, and the very existence of a dependent."17

Because of its constitutional stature, the inherent power doctrine serves as a lever by which the courts can demand payment of their expenses even during times of fiscal crisis affecting the government as a whole. In Tate, for example, the court acknowledged Philadelphia's financial difficulties but nevertheless argued that "the deplorable financial conditions in Philadelphia must yield to the constitutional mandate that the judiciary shall be free and independent and able to provide an efficient and effective system of Justice."18

15274 A.2d at 199.

247 Ind. 631 , 220 N.E.2d 532 (1966).

17220 N.E.2d at 534. In Smith v. Miller, 153 Colo. 35, 384 P.2d 738 (1963), the Colorado Supreme Court made a similar argument. In that case, the judges of a Colorado district court had sent a list of requested court employee salaries to their county commissioner. Refusing to approve the requested salaries, the commissioner set the court employees' salaries according to the pay scale used for all other county employees. The Smith court affirmed the district court judges' inherent power to set court employees' salaries and required the county commissioner to follow the judges' determinations. The court argued that "[i]t is not only exiomatic [sic], it is the genius of our government that the courts must be independent, unfettered, and free from directives, influence, or interference from any extraneous source. It is abhorrent to the principles of our legal system and to our form of government that courts, being a coordinate department of government, should be compelled to depend upon the vagaries of an extrinsic will." 384 P.2d at 741.

18274 A.2d at 199. See also id. at 202 (Pomeroy concurring):

No evidence is required to establish that the government is at all levels experiencing severe financial strains. As the opinion of the Court points out, however, the court 
State courts applying the inherent power doctrine have agreed on the doctrine's substantive content: it empowers state courts to compel public appropriation for "reasonable and necessary" expenses related to the judicial function. ${ }^{19}$ Courts exercising their inherent power need not demonstrate that they had to invoke the power in order to perform their constitutional duties (for example, in order to provide litigants with due process of law). Rather, reviewing courts characteristically have upheld lower courts' use of their inherent power to compel public appropriations in any situation where the appropriation relates to the court's day-to-day functioning. Reviewing courts, for example, have upheld lower courts' exercise of their inherent power to set salaries for supporting personnel, to requisition space needed for courtroom facilities, and even to demand that the executive provide an operator for the courthouse elevator. ${ }^{20}$

Reviewing courts have not required lower courts to demonstrate that the legislative alternative to the court's exercise of inherent power would necessarily have harmed the court. In Carlson $v$. State, for example, the Indiana Supreme Court upheld the city court's exercise of its inherent power to set court employees' salaries even though the city council proposed a reasonable alternative-that the county pay court employees according to the same scale as all other county employees. ${ }^{21}$

system in Philadelphia is not just another competing cause or need; it is itself a separate branch of government, co-equal with the executive and legislative branches headed by the defendants in this case. The distinction is not one of degree, but of kind. No doubt the courts must be mindful, in making the estimates of their financial needs, of the needs of the total community and of the problems of the legislative branch in funding them; but the courts having made their determination as being reasonably necessary to performance of their constitutional functions, it is not for the legislative branch to deny the reasonableness or the necessity on the ground that something else is more urgent or more important.

19 See, for example, Board of County Commissioners v. Judicial Space, etc., 378 So.2d 1247 (Fla. 1979) (court has the inherent power to requisition "necessary" space); Judges for the Third Judicial Circuit v. County of Wayne, 383 Mich. 10, 172 N.W.2d 436, 441 (1969) (courts have the power to obligate the county contractually for items of expense "necessary to the effectively continuing functioning of the court"), modified by 386 Mich. 1, 190 N.W.2d 288 (1971); In re Clerk Court's Compensation of Lyon County v. Lyon County Commissioners, 308 Minn. 172, 241 N.W.2d 781 (1976) (if established procedures fail, court may appropriate funds it needs as a "practical necessity" to perform its judicial function).

${ }^{20}$ See Board of Commissioners of Vigo County v. Stout et al., 136 Ind. 53, 35 N.E. 683 (1893) (elevator case), and cases cited in note 19.

21220 N.E.2d at 532. 
B. The Inherent Power Doctrine Should Not be Applied in the Federal Context

Extended to the federal government, the inherent power doctrine would stand for the proposition that the Constitution implicitly grants the federal courts authority to "self-execute"22 their own budget demands by bypassing Congress and appropriating public funds for the courts' operating expenses. The federal courts would have this authority because the federal judiciary exists as an independent governmental entity, and because Congress might otherwise frustrate the constitutional checks and balances system by underfunding of the federal courts.

This section argues that the federal courts should not use the inherent power doctrine as a response to Congressional underfunding of civil juries. Two difficulties preclude application of the inherent power doctrine in the federal appropriation context. First, the Constitution's text argues against recognition of the courts' inherent power to appropriate public funds. Second, acceptance of the judiciary's inherent power to appropriate funds would create a dangerous precedent likely to produce harmful economic and political consequences; the Supreme Court has recognized this danger and has refused to uphold broad, self-executing powers in related contexts.

1. Textual Problems.

a. Congress' appropriations power. Article I provides that "No Money shall be drawn from the Treasury, but in Consequence of Appropriations made by Law" and says that "All Bills for raising Revenue shall originate in the House of Representatives." ${ }^{23}$ This language which explicitly locates the power to make federal appropriations exclusively in Congress denies the federal courts any inherent power to appropriate public funds.

In National Association of Regional Councils v. Costle, ${ }^{24}$ for example, the D.C. Circuit, although admitting that equity favored

${ }^{22}$ When state courts use their inherent powers to appropriate funds, they "self-execute" their budget demands rather than suing for a judgment to execute those demands. If displeased with the legislature's appropriation, state court judges need not demonstrate their legal entitlement to the extra money in a court of law: by virtue of the inherent power doctrine, the judges have the immediate power to override the appropriation by sending a writ of mandamus to the state treasury. See 20 Am.Jur.2d Courts $\S 78$ at 440 ("The phrase 'inherent powers' is used to refer to powers included within the scope of a court's jurisdiction which a court possesses irrespective of specific grant by constitution or legislation. Such powers can neither be taken away nor abridged by the legislature.").

${ }^{23}$ U.S.Const. art. I, § 9, cl. 7; Id. at § 7 .

24564 F.2d 583 (D.C.Cir. 1977). 
the lower court's decision, reversed a district court order because it had, in effect, ordered an appropriation from the U.S. Treasury not supported by law. Pursuant to the Water Pollution Control Act, Congress had directed the Environmental Protection Agency (EPA) in fiscal years 1973 and 1974 to distribute a sum of appropriated funds among state and regional agencies formed to oversee waste treatment management plans. The EPA failed to spend all of the allocated money, and an association of regional agencies sued demanding that the EPA pay out the remaining funds. Even though the EPA's budgetary authority to spend these funds had expired at the time plaintiffs brought suit, the district court held that because the EPA had failed to take full advantage of the congressional appropriation in 1973 and 1974, the court could reinstate the EPA's budgetary authority to spend these funds through 1977.

Admitting that the EPA had frustrated congressional intent by letting its budgetary authority die before spending the waste treatment management funds, the D.C. Circuit nevertheless reversed the lower court. The court held that "any order of the court to obligate public money conflicts with the constitutional provision vesting sole power to make appropriations in the Congress." The court explained that "[e]quity empowers the courts to prevent the termination of budget authority which exists, but if it does not exist, either because it was never provided or because it has terminated, the Constitution prohibits the courts from creating it no matter how compelling the equities." ${ }^{25}$ The district court erred because it had ordered an appropriation that had no basis in law, either statutory or constitutional.

Arguably, however, a federal court might assert that an inherent power to appropriate funds is authorized by law. As state courts have argued in related contexts, the creation of three coequal branches in the federal Constitution-the "paramount law"26 - confers upon all three branches the power to appropriate money. Accepting this structural argument, however, nullifies Article I's grant of exclusive appropriation power to Congress. If the

${ }^{25} 564$ F.2d at 589. See also United States v. Board of Education of City of Chicago, 744 F.2d 1300 (7th Cir. 1984), vacating 588 F.Supp. 132 (N.D.Ill. 1984) (vacating district court order calling for executive branch to lobby Congress for funds); Geoffrey C. Hazard, Martin B. McNamara, and Irwin F. Sentilles III, Court Finance and Unitary Budgeting, 81 Yale L.J. 1286, 1289-90 (1972) ("A judicial requisition of funds from a taxing agency, such as a county or city, is in essence a judicial arrogation of discretion conferred, for better or worse, on the popularly-elected branches of government.").

${ }^{26}$ Marbury v. Madison, 5 U.S. 137, 177 (1803). 
judiciary and the executive both have the power to appropriate federal funds, then against whom is the congressional appropriation power exclusive?

b. Congress' plenary control over the inferior federal courts. The Constitution vests Congress with plenary power to create or disband inferior federal courts; this suggests that the Constitution cannot be read to imply that lower federal courts must have an inherent power to order the appropriation of public funds in order to ensure their own survival. ${ }^{27}$ Although the Federal Constitution establishes a tripartite form of government, and although the framers enthusiastically supported the separation of powers, ${ }^{28} \mathrm{Ar}$ ticle III specifically delegates to Congress the authority to vest the federal judicial power in such inferior federal courts "as the Congress may from time to time ordain and establish."29

The Supreme Court, moreover, consistently has held that Congress not only has the power to create inferior federal courts but also may exclude from the jurisdiction of the inferior federal courts categories of cases to which the federal judicial power extends. The Court has stated that "[ $t]$ he Congressional power to ordain and establish inferior courts includes the power "of investing them with jurisdiction either limited, concurrent, or exclusive, and of withholding jurisdiction from them in the exact degrees and character which to Congress may seem proper for the public good." "so

In Sheldon $v$. Sill, ${ }^{31}$ for example, Congress had withdrawn lower federal court jurisdiction from diversity cases where the diversity was created by an assignment of rights, thereby precluding

27 This argument does not apply to the Supreme Court, because the Constitution mandates that Court's existence. U.S.Const. art. III, § 1 .

${ }^{28}$ See Federalist 48 and Federalist 51 (Madison), in Jacob E. Cooke, ed., The Federalist 332,347 (1961).

${ }^{20}$ U.S.Const. art. III, $\S 1$. Although initially a question for debate, the view that the Constitution does not mandate that Congress create inferior federal courts has prevailed. See Paul M. Bator, Congressional Power over the Jurisdiction of the Federal Courts, 27 Vill.L.Rev. 1030, 1031 (1982). The provision granting Congress plenary power over the inferior federal courts resulted from a compromise between those framers who "thought that the Constitution itself should establish a full set of federal courts, and those who thought that the Constitution should authorize no federal courts inferior to the Supreme Court whatever." "The central premise of the compromise," according to Professor Bator, "was the insight that the question whether a given 'federal' case should initiate in a state court (subject to Supreme Court review), or in a lower federal court, is not an appropriate question for a decision at the constitutional level. Rather, Congress is the body best suited to make this institutional judgment on the basis of changing circumstances." Id.

so Lockerty v. Phillips, 319 U.S. 182, 187 (1943), quoting Cary v. Curtis, 44 U.S. 236, 245 (1845).

s1 49 U.S. 441 (1850). 
the lower federal courts from hearing a category of cases within the federal judicial power. The Sheldon Court, upholding the Congressional action, argued that since the Constitution vests Congress with the power to prescribe inferior federal courts, "Congress may withhold from any court of its creation jurisdiction of any of the enumerated controversies. Courts created by statute can have no jurisdiction but such as the statute confers." 32

One cannot consistently contend that the Constitution grants Congress plenary power to create and define the jurisdiction of inferior federal courts while also arguing that the Constitution creates an inherent power in the lower federal courts to guarantee their own survival by appropriating public funds. Unlike the United States Constitution, many state constitutions mandate the creation of general jurisdiction courts. State courts have emphasized this aspect of their constitutional plans when applying the inherent power doctrine. ${ }^{33}$ Unlike state courts, the lower federal courts are subject to Congressional control at every point, from their very existence to the types of cases they may hear. While it may be legitimate to infer a self-protecting appropriation power deriving from state constitutions' creation of independent state courts of general jurisdiction, no such inference is legitimate in the federal context.

2. Dangerous Precedent. The inherent power doctrine as defined by state courts in the appropriation context represents a very expansive power. Acceptance of the doctrine means that courts may appropriate public funds for purposes having only an attenuated connection to the courts' constitutional responsibilities.

By allowing courts to bypass the legislative branch and "selfexecute" their own budget demands, the doctrine promotes fiscal irresponsibility. All sectors of government frequently receive less than ideal financing and must respond by making difficult sacrifices, but the inherent power doctrine provides courts with a constitutional deus ex machina, rescuing the judiciary from this sectarian strife. The doctrine allows the judiciary to forget budget consciousness. By investing courts' day-to-day spending with constitutional significance, the inherent power doctrine "diverts attention from the truly critical budgeting task facing the courts: choosing priorities among goals and objectives, since there will never be sufficient funding to do everything that might reasonably be

s3 See, for example, Smith v. Miller, 153 Colo. 35, 384 P.2d 738 (1983). 
thought necessary in an ideal system of justice." ${ }^{34}$

The judiciary's use of the inherent power doctrine to reprioritize the budget so that the judiciary gets whatever it needs is not cost free. By reducing funds available for other governmental operations, the judiciary's use of the doctrine damages other governmental institutions to the degree that it benefits the judiciary. Granting the judiciary the autonomy to demand public funds for its operating expenses creates the risk that the judiciary might abuse the power for socially undesirable ends. For example, a district court might decide to build a more spacious courthouse and, assuming that appropriating money for a new courthouse fell within the courts' inherent power, Congress might then have to cut the enforcement of food and drug regulations or transfer money that Congress had initially budgeted to aid inner-city schools..$^{35}$

Proponents of the inherent power doctrine might argue that the possibility of fiscal irresponsibility on the part of the federal courts cannot possibly have much impact on the government's overall economic health, because money spent on the courts comprises such a small percentage of the government's total budget. ${ }^{36}$ Even assuming that the judiciary's limited needs would not pose a serious economic threat, recognizing an inherent power to appropriate funds would presage serious economic dangers: recognizing this power in the judiciary would imply the existence of a similar self-executing power in the executive branch.

The same separation of powers arguments that justify the inherent spending power in the judiciary also justify an inherent

34 Hazard, McNamara, and Sentilles, 81 Yale L.J. at 1291 (cited in note 25).

ss Part II of this comment argues that courts can enforce the seventh amendment's requirement that Congress provide funds for civil jury trials. Arguably, this may cause Congress to pay for civil jury trials by diverting money that might have been spent for what many would consider more socially useful purposes. This comment takes the position that because the Constitution is binding law, Congress cannot dispose of constitutional guarantees through value judgments but rather must wait for a constitutional amendment before refusing to fund civil juries.

so The size of the federal judiciary's budget should not be underestimated, however; for the fiscal year 1984, the federal courts administered a budget of $\$ 875,104,000$. Administrative Office of the United States Courts, The United States Courts: A Pictorial Survey, chart 14 (1984). For the argument that recognizing state courts' inherent power to appropriate funds will not produce fiscal chaos because state courts have limited needs, see Morgan County Commission v. Powell, 292 Ala. 300, 293 So.2d 830, 853 (1974) (Heflin dissenting). Tate, however, illustrates that despite their limited functions, courts, if given the inherent power to appropriate funds, might use the power to make damaging appropriations. 274 A.2d at 200 . In that case, the common pleas court employing the inherent power doctrine demanded \$ 2.46 million for five months' expenses from financially strapped Philadelphia's treasury. 
spending power in the executive. If the Constitution entitles the judiciary to appropriate its own funds because the Constitution creates an independent judiciary and because otherwise the legislature, through inadequate funding, might prevent the judiciary from carrying out its constitutional function, then the Constitution must also entitle the executive to appropriate funds because the Constitution creates an independent executive and because otherwise the legislature, through inadequate funding, might prevent the executive from carrying out his or her constitutional function.

Recognizing the judiciary's inherent power to appropriate public funds, then, would vest the President with the power to bypass Congress and self-execute his or her own budget demands. The President must, for example, have the power to appropriate money for the military because otherwise, Congress might prevent the President from carrying out his or her responsibilities as commander-in-chief of the armed forces. ${ }^{37}$

The logic of the inherent power doctrine might possibly be extended even further. If the Supreme Court, for example, recog-

s7 U.S.Const. art. II, § 2, cl. 1 .

With the exception of Tate, 274 A.2d 193, the elevated constitutional rhetoric employed by state courts when advancing the inherent power doctrine has not reflected the gravity of the particular appropriations at issue. The doctrine has been asserted predominately by state courts making marginal appropriations for ancillary personnel and facilities. Hazard, McNamara and Sentilles have argued that state court reliance on the inherent power doctrine "may be shortsighted and unwise" because in the cases recognizing the power, the party whose appropriation has been challenged' (usually the legislature but sometimes the executive) has not had sufficient motivation to protest fully:

In the minority of cases where the judiciary has proceeded against the state legislative or executive branch in a direct contest, the issue involved has always been specific, narrow, and relatively minor. Although the state's executive and legislative branches are directly confronted, they are not challenged in any vital way. Acquiescence to the doctrine of inherent power appears to follow from a considered unwillingness to pursue the contest further, rather than any real disability to do so. There is a reluctance to jeopardize the tripartite structure of government over a few dollars for a janitor's or a stenographer's salary.

81 Yale L.J. at 1287-89 (cited in note 25).

It might be argued, therefore, that although as a doctrinal matter the inherent power doctrine frees government officials to self-execute their budgetary requests unchecked, experience at the state level suggests that officials vested with this power will not abuse it. However, state courts might not have taken full advantage of the inherent power doctrine simply because most states have not yet definitively accepted the doctrine. Moreover, some state judges, unlike their federal counterparts, must seek reelection: "[T]here comes a time when a judge or any other public official must make an accounting to the voters for his actions, if arbitrary, extravagant, or not in the public interest, and that is true of a city judge or any judge in the State." Carlson v. State, 220 N.E.2d at 536. Even though recognition of the inherent power doctrine has not led to devastating results at the state level, federal courts should not create the potential for abuse of power at the federal level by recognizing the federal courts' inherent power to appropriate funds. 
nized the inferior federal courts' inherent power to appropriate public funds, could the Court contain this precedent within the appropriation context? Or would this precedent stand for the broader proposition that the federal judiciary has the inherent power to take any action the judiciary decides it needs to take in order to meet its constitutional responsibilities? If this precedent comes to stand for this broader proposition, how could the Court deny that the Constitution also gives the President the power to take any action he or she deems necessary to fulfill his or her constitutional responsibilities, even an action explicitly proscribed by statute?

The Supreme Court has recognized the danger implicit in acknowledging broad self-executing inherent powers. For example, in a seminal separation of powers case, Youngstown Sheet \& Tube Co. v. Sawyer ("The Steel Seizure Case"), ${ }^{38}$ the Supreme Court refused to read inherent powers into the Constitution's delegation of responsibilities.

In that case, President Truman, fearing that a nationwide steel strike would cripple America's effort in the Korean War, ordered the Secretary of Commerce to take control over most of the nation's steel mills. Truman claimed that his power to seize the mills derived from "the aggregate of his powers under the Constitution," specifically his power as commander-in-chief and his power to execute the laws. ${ }^{39}$

The majority rejected this argument. Emphasizing the danger implicit in recognizing the autonomy sought by President Truman, the Court first declined to read the power to seize the mills into the President's responsibility as commander-in-chief: "Even though 'theater of war' be an expanding concept, we cannot with faithfulness to our constitutional system hold that the Commander in Chief of the Armed Forces has the ultimate power as such to take possession of private property in order to keep labor disputes from stopping production." ${ }^{30}$ Next, the Court rejected President Truman's executive power argument, refusing to accept Truman's broad definition of the power to execute the laws: "The President's order does not direct that a congressional policy be executed in a manner prescribed by Congress-it directs that a presidential policy be executed in a manner prescribed by the President."41

Justice Jackson's famous concurrence in Youngstown argued

s8 343 U.S. 579 (1952).

s9 Id. at 587 .

10 Id.

4 Id. at 588 . 
that "presidential powers are not fixed but fluctuate, depending upon their disjunction or conjunction with those of Congress."42 Jackson grouped exercises of presidential power under three models. In the first model, where the President acts pursuant to an express or implied authorization of Congress, presidential authority is at its maximum. Cases where the President acts in absence of any specific congressional pronouncement comprise the second category; "[i]n this area, any actual test of power is likely to depend on the imperatives of events and contemporary imponderables rather than on abstract theories of law."43 Jackson's third and most problematic category contains cases where the President acts contrary to the expressed or implied will of Congress. Jackson argued that "[c]ourts can sustain exclusive presidential control in such a case only by disabling the Congress from acting upon the subject. Presidential claim to a power at once so conclusive and preclusive must be scrutinized with caution, for what is at stake is the equilibrium established by our constitutional system."44

Significantly then, the Court has recognized that separation of powers concerns disfavor recognizing the President's-or by the same principle the judiciary's - ability to act directly contrary to Congressional will. The judiciary's exercise of an inherent power to appropriate public funds would fall within Jackson's problematic third category: presumably, inferior federal courts would only exercise their inherent power when, in the courts' view, congressional appropriations were inadequate.

Jackson's concurrence undermines the theoretical justification for recognizing the courts' inherent power to appropriate public funds. State courts have argued that they need the inherent power to appropriate public funds because otherwise the legislature might subvert the judiciary's independence; in order to preserve the state constitutional separation of powers, each branch must remain capable of surviving without the other two. Jackson's approach toward separation of powers is more functional: rather than discussing the need for each branch's autonomy, Jackson implies that any action that disrupts the traditional allocation of responsibilities among the three branches offends the federal separation of powers. Rather than requiring each branch's complete independence, the federal separation of powers seeks precisely to create a system of interdependence, limiting each branch's power by leav-

${ }^{42}$ Id. at 635 (Jackson concurring).

${ }^{43}$ Id. at 637 (Jackson concurring).

44 Id. at 637-38 (Jackson concurring). 
ing each branch dependent upon the other two. ${ }^{45}$ Granting the federal courts the power to bypass the legislature by way of self-executing budget proposals would defeat this constitutionally created separation of powers.

\section{The Seventh Amendment as an Enforceable Limit on Congressional Appropriation Power}

Part I of this comment argued that the federal courts do not have a self-executing power to appropriate their budget demands because the Constitution vests the appropriation power exclusively in Congress. Arguing that Congress has the exclusive power to appropriate does not, however, mean that the Constitution places no limitations on Congress' exercise of that power. The Constitution frequently both grants a power exclusively to a particular branch of government and limits that branch's exercise of the exclusive power: the executive, for example, has the exclusive power to carry out the laws, but the eighth amendment prohibits the executive from eliciting confessions through torture.

Part II of this comment argues that the seventh amendment places a limitation on Congress' appropriation power. That amendment places an affirmative duty upon the federal government to provide civil jury trials in federal court where a jury trial would have been available at common law at the time the Constitution was ratified. If the government is to comply with this constitu-

45 Madison shared Jackson's belief that the federal separation of powers creates an interdependence among the three branches rather than three autonomous entities. Madison wrote that the constitutional separation of powers "goes no farther than to prohibit any one of the entire departments from exercising the powers of another department." Federalist 47, in Cooke, ed., The Federalist 323, 328 (cited in note 28). See also Joseph Story, 2 Commentaries on the Constitution of the United States $\$ 539$ (1833) (a limitation of powers could be best accomplished by an occasional mixing of those powers); Charles Louis de Montesquieu, The Spirit of the Laws, 150-160 (Harner ed. 1949) (interdependence is essential to any general division of powers because no group of men can be relied upon to limit their own powers).

Jackson's interpretation of the federal separation of powers does not imply that state courts that have recognized an inherent power to self-execute their budget requests have incorrectly interpreted their state constitutions. Federal law might inform a state court's interpretation of its own constitution but, as long as no federal rights are implicated, federal law does not control the interpretation of a state constitution. State courts have the prerogative, therefore, to read their state constitutions as requiring each branch of their state government's complete independence. See, e.g., Paul G. Kauper, The State Constitution: Its Nature and Purpose 11 (1961) (the reformers of the Michigan state constitution "may not anticipate all the situations where some departure from the separation principle is warranted. It [therefore] may be more suitable simply to recognize the separate departments in the Constitution, and leave the implications of the separation principle to be worked out on the basis of experience and judicial construction."). 
tional duty, Congress must provide the necessary funds. As a result, this comment takes the position that in an instance where a federal district court denies a litigant a civil jury trial because of congressional underfunding, the Constitution authorizes a reviewing court to order the district court to empanel a jury. The district court should then empanel a jury and send the bill for jury empaneling to Congress. ${ }^{46}$ Part II of this comment considers two issues. The first issue is whether, as an institutional matter, a federal court should reach the merits on a claim that the seventh amendment places a limitation on the appropriation power. The second issue is whether the seventh amendment both requires the government to provide litigants in federal court with a civil jury trial and requires Congress to provide the necessary money for empaneling juries.

\section{A. The Threshold Question: Justiciability}

Part I of this comment concluded that the Constitution grants Congress the exclusive power to appropriate public funds. Arguably, this conclusion compels an ancillary one: if the Constitution gives Congress the exclusive power to appropriate, then the Constitution must also intend for the appropriation power to remain immune from judicial review, even if the Constitution places restrictions on Congress' exercise of that power.

The Court's opinion in the seminal political question case, Baker $v$. Carr, ${ }^{47}$ might be read to support this position. In that case, the Court listed the factors likely to indicate a nonjusticiable political question, stating in dicta that "[p]rominent on the surface of any case held to involve a political question is found a textually demonstrable constitutional commitment of the issue to a coordinate political department." ${ }^{48}$

16 If Congress refuses to pay the jury empaneling expenses, the jurors should sue the government for their salaries and expenses. 28 U.S.C. $\$ 1346(a)(2)$ grants district courts jurisdiction of any "civil action or claim against the United States, not exceeding $\$ 10,000$ in amount, founded . . . upon the Constitution." Since jurors are presently paid $\$ 30.00$ per day, plus some expenses, and receive these payments twice monthly, the $\$ 10,000$ amount limit would not present any problems. See 28 U.S.C. $\$ 1871$ (1982) (covering payments to jurors).

369 U.S. 186 (1962).

48 Id. at 217. The other factors listed by the Baker Court were a "lack of judicially discoverable and manageable standards for resolving it [the dispute]; or the impossibility of deciding without an initial policy determination of a kind clearly for nonjudicial discretion; or the impossibility of a court's undertaking independent resolution without expressing lack of the respect due coordinate branches of government, or an unusual need for unquestioning adherence to a political decision already made; or the potentiality of embarrassment from 
Baker, then, arguably indicates that the Constitution's commitment of the appropriation power to Congress precludes judicial enforcement of constitutional limitations on that power, and some courts in fact have held that the Constitution immunizes appropriation decisions from judicial review. ${ }^{49}$ Reading the Baker dicta this forcefully, however, conflicts with the long history of judicial review in this country and specifically contradicts the Court's holdings in a number of cases where the Court has reached the merits of claims that Congress has exercised its appropriation power unconstitutionally.

Accepting the argument that the federal courts may not review acts representing exercises of powers granted exclusively to another branch goes far toward destroying the courts' ability to question the constitutionality of any federal government action. Practically every power granted in the Constitution is "exclusive." ${ }^{\text {so }}$ The Constitution, for example, grants Congress the exclusive power to regulate commerce, but no one would argue that this grant implies that federal courts have no power to intervene if Congress passes a law denying blacks and whites equal access to markets. Likewise, the Constitution grants the President exclusive authority to execute the laws, but federal courts routinely decide if federal law enforcement agents have complied with the fourth amendment. ${ }^{.1}$

multifarious pronouncements by various departments on one question." Id.

The Court subsequently has suggested that a showing of a "textually demonstrable commitment" might standing by itself be conclusive. See Powell v. McCormack, 395 U.S. 486, 518-49 (1969); Comment, The Guarantee of Republican Government: Proposals for Judicial Review, 54 U.Chi.L.Rev. 208, 217 (1987) (reading Powell in this manner); Herbert Weschler, Toward Neutral Principles of Constitutional Law, 73 Harv.L.Rev. 1, 8 (1959). This comment takes the position that these other factors are irrelevant in the present context because courts routinely decide issues similar to appropriations for civil juries, and because courts do have standards by which they can evaluate the constitutionality of a denial or delay in empaneling a civil jury. These standards derive from the seventh amendment and the analysis set out in Part III of this comment.

40 See, for example, Spaulding v. Douglas Aircraft, 60 F.Supp. 985 (S.D.Cal. 1945) ("Any attempt by the judicial branch to interfere with the exclusive [appropriation] powers of Congress would be a plain invasion of the powers of said body conferred upon it by the Constitution of the United States.").

so Ironically in light of the Baker dicta, courts consistently decline to review constitutional challenges to the war making power, which is one of the few powers arguably granted to more than one branch. U.S.Const. art. I, $\$ 8$, cl. 11 (Congress has power to declare war); Id. at art. II, § 2, cl. 2 (President is commander-in-chief). See, for example, Holtzman v. Schlesinger, 484 F.2d 1307 (2d Cir. 1973) (Cambodian bombing nonjusticiable); Atlee v. Laird, 347 F.Supp. 689 (E.D.Pa. 1972) (legality of Vietnam War nonjusticiable).

${ }^{s}$ See, for example, Bivens v. Six Unknown Named Agents of the Federal Bureau of Narcotics, 403 U.S. 388 (1971). 
The above analysis suggests that Courts cannot accept the principle that constitutional challenges to congressional appropriations decisions are nonjusticiable merely because the Constitution grants the power to appropriate to Congress alone. This argument depends upon the consequences of reaching a contrary conclusion: if exclusivity of power indicates a nonjusticiable political question, then judicial review of federal government action no longer exists. This argument from consequences is weaker, however, if courts can distinguish between the appropriation power and other exclusive powers by arguing that the Constitution's text contains a special emphasis on the exclusivity of Congress' appropriation power. The Constitution lists Congress' appropriation power in the same manner as it enumerates the other powers granted Congress: "The Congress shall have Power To lay and collect Taxes . . . and provide for the common Defence and the general Welfare." $"{ }^{2}$ But the Constitution arguably distinguishes between the appropriation power and other congressional powers by making a later reference to the exclusivity of Congress' power to appropriate in Article I, Section 9: "No Money shall be drawn from the Treasury, but in Consequence of Appropriations made by Law."

Although this textual distinction could be relevant, Supreme Court precedent indicates that it does not matter. By reaching the merits in a number of cases challenging the constitutionality of congressional appropriations, the Court has implicitly rejected the argument that attacks on appropriations decisions are nonjusticiable. In U.S. $v$. Will, ${ }^{54}$ for example, the Court reached the merits of a class action brought by federal judges. The judges argued that the 1979 congressional appropriation for federal judges' salaries offended the compensation clause ${ }^{55}$ by repealing previously enacted salary increases. Never mentioning the possibility of nonjusticiability, the Court immediately addressed the constitutional question: "when, if ever, does the Compensation Clause prohibit the Congress from repealing salary increases that otherwise take effect automatically pursuant to a formula previously enacted?"s6

Likewise, in the earlier case of Flast $v$. Cohen, ${ }^{57}$ the Court reached the merits of a claim that Congress had violated the estab-

${ }^{32}$ U.S.Const. art. I, § 8, cl. 11.

ss U.S.Const. art. I, § 9, cl. 7 .

s4 449 U.S. 200 (1980).

${ }^{B S}$ U.S.Const. art. III, $\S 1$ ("Judges . . . shall . . . receive for their Services, a Compensation, which shall not be diminished during their Continuance in Office").

${ }^{38} 449$ U.S. at 221.

${ }^{87} 392$ U.S. 83 (1968). 
lishment and free exercise clauses of the first amendment by partially financing religious schools. The Court explicitly stated that the first amendment cabins Congress' appropriation power: "the Establishment Clause was designed as a specific bulwark against such potential abuses of governmental power, and that clause of the First Amendment operates as a specific constitutional limitation upon the exercise by Congress of the taxing and spending power conferred by Art. I, Sec. 8." recognized its authority to enforce these constitutional limits: although failing to find a violation of the religion clauses, the Court confronted the constitutional issues rather than declining consideration on nonjusticiability grounds.

In sum, then, both the American tradition of judicial review in general and Supreme Court precedent reviewing congressional appropriations in particular suggest that courts may decide claims that the government has denied a litigant his or her seventh amendment rights due to underfunding of juries. This conclusion seems especially true in light of the controversy here. Underlying the political question doctrine is a sense that some issues are inappropriate for judicial resolution. ${ }^{58} \mathrm{By}$ contrast, the situation here-judicial enforcement of a bill of rights provision against one of the political branches-represents the paradigmatic example of a correct and appropriate exercise of judicial review. The issues presented by the seventh amendment are not political questions because the rights of citizens against the government are at stake, not the rights of the judiciary against another branch.

Even advocates of judicial restraint recognize that courts play a legitimate and necessary role when they protect personal liberties explicitly listed in the bill of rights against the encroachment of one of the political branches. Judge Robert Bork, for example, has argued that the source of judicial review's legitimacy limits its proper scope. Although countermajoritarian, judicial review is jus-

ss Id. at 104.

s9 See Alexander M. Bickel, The Least Dangerous Branch 184 (1962) ("Such is the foundation, in both intellect and instinct, of the political-question doctrine: the Court's sense of lack of capacity, compounded in unequal parts of (a) the strangeness of the issue and its intractability to principled resolution; (b) the sheer momentousness of it, which tends to unbalance judicial judgment; (c) the anxiety, not so much that the judicial judgment will be ignored, as that perhaps it should but will not be; (d) finally . . . the inner vulnerability, the self-doubt of an institution which is electorally irresponsible and has no earth to draw strength from."). See also Fritz W. Sharpf, Judicial Review and the Political Question: A Functional Analysis, 75 Yale L.J. 517, 567 (1966) (application of the political question doctrine justified when the court cannot reach an intelligent decision because it lacks access to necessary information). 
tified when courts act pursuant to explicit provisions in the bill of rights because these provisions represent society's consent "to be ruled undemocratically within defined areas by certain enduring principles believed to be stated in, and placed beyond the reach of majorities by, the Constitution."

Likewise, a restrictive, process-based theory of judicial review would accept court enforcement of the seventh amendment. This view tries to reconcile the countermajoritarian nature of judicial review with the Constitution's decision to create a democratic system of government by suggesting that judicial review is appropriate if it facilitates the efficacy of the democratic process-if it, for example, protects people's abilities to participate in the democratic process. $^{61}$ The civil jury system represents a check upon abuse of the democratic process incorporated in the Constitution by its framers. ${ }^{62}$ If the democratic process fails and special interest groups manage to impose their will upon the majority through law, a jury composed of a cross-section of the community can, for various reasons, refuse to enforce the law.

B. The Substantive Argument: The Seventh Amendment Places an Affirmative Obligation on the Government to Provide Civil Litigants in Federal Court with a Jury

Assuming that a court can enforce the seventh amendment even if, in so doing, the court overturns a congressional appropriations decision, does the seventh amendment actually place an obligation on the government to provide civil litigants in federal court with juries, and a consequent obligation on Congress to provide funds for those juries? This section first demonstrates that federal litigants have a right to a jury trial in appropriate cases. It then tries to reconcile this conclusion with the understanding, held by some, that the Constitution does not impose affirmative obligations on the government.

1. The Seventh Amendment Applies to Federal Proceedings. By its terms, the seventh amendment does not mention federal courts; rather, it guarantees the right to jury trial "[i]n suits at common law, where the value in controversy shall exceed twenty

${ }^{60}$ Robert H. Bork, Neutral Principles and Some First Amendment Problems, 47 Ind.L.J. 1, 3 (1971).

${ }^{61}$ See generally John Hart Ely, Democracy and Distrust (1980).

${ }^{62}$ See generally Charles W. Wolfram, The Constitutional History of the Seventh Amendment, 57 Minn.L.Rev. 639 (1973). 
dollars." ${ }^{\text {B3 }}$ Conceivably, state courts might satisfy this constitutional guarantee: litigants have access to general jurisdiction state courts, and state courts provide civil juries. ${ }^{64}$ Because the seventh amendment creates a waivable personal right rather than imposing a jurisdictional mandate upon courts, the federal district courts have authority to adjudicate common law civil claims absent a jury. ${ }^{60}$ Conceivably then, in a system where state courts provide civil juries and where state and federal courts have concurrent jurisdiction, a litigant, by deciding to appear in federal court, might implicitly waive his or her seventh amendment right. The relevant question here, therefore, is whether the seventh amendment specifically requires that federal courts provide civil jury trials.

The Supreme Court believes that the seventh amendment guarantees civil litigants in federal court the right to a jury trial. Language in Supreme Court opinions frequently describes the civil jury trial right as an essential prerogative of the federal court system. ${ }^{66}$ And, a number of Supreme Court holdings imply that the

63 U.S.Const. amend. VII.

64 Some courts and commentators who have questioned the sanctity of the right to a jury trial might argue that state courts satisfy the seventh amendment guarantee. Some courts have carved out exceptions to the seventh amendment's applicability in federal court, see note 68 , and commentators have long criticized the civil jury's efficacy. See generally, Jerome Frank, Courts on Trial (1949). Some commentators, moreover, have suggested that a federal judge should honor a civil litigant's jury demand only when the judge determines that the litigant's trial will be unfair without a jury. One commentator has stated that courts should "take into account the disappearance of conditions that in the 18th century required the protection of the vox populi in civil matters. According to this view, the common law jury's function was very specifically to protect citizens from unfair trials, and if a jury would not protect people from unfair trials, then its use would be dysfunctional." Mary Kay Kane, Civil Jury Trial: The Case for Reasoned Iconoclasm, 28 Hastings L.J. 1, 2 (1976).

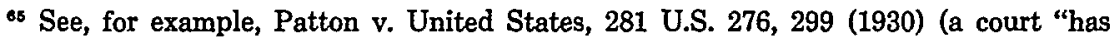
authority . . . to accept the waiver, and, as a necessary corollary, to proceed to the trial and determination of the case with a reduced number or without a jury." Id. at 299 . See also K.M.C. Co., Inc. v. Irving Trust Co., 757 F.2d 752, 755 (6th Cir. 1985) (a party may contractually waive his right to jury trial); Fed.Rule Civil Proc. 38(d) (a party waives his or her right to a jury trial unless the party demands a jury in accordance with the procedures outlined in the Federal Rules); Perego v. Dodge, 163 U.S. 160, 166 (1896) (prior to Federal Rules of Civil Procedure, a party waived his right to a jury trial if he failed to make a timely objection to a bench trial).

os See, for example, Jacob v. New York City, 315 U.S. 752, 752-53 (1941) ("[T]he right of jury trial in civil cases at common law is a basic and fundamental feature of our system of federal jurisprudence which is protected by the Seventh Amendment. A right so fundamental and sacred to the citizen, whether guaranteed by the Constitution or provided by statute, should be jealously guarded by the courts."); Scott v. Neely, 140 U.S. 106, 109-110 (1891) ("In the Federal courts this (jury) right cannot be dispensed with, except by the assent of the parties entitled to it, nor can it be impaired by any blending with a claim, properly cognizable at law, of a demand for equitable relief in aid of the legal action or during its pendency. Such aid in the Federal courts must be sought in separate proceedings, to the end 
Court believes federal litigants have a civil jury trial right. ${ }^{67}$ The lower federal courts apparently share this belief: appellate and district courts frequently consider whether cases exist where the court should deny a federal litigant's civil jury demand. The attempt to identify these cases implies an underlying rule that the seventh amendment guarantees the federal litigant a civil jury trial in all but exceptional circumstances. ${ }^{68}$

\section{Possibly because the belief in a federal civil jury trial right}

that the right to a trial by a jury in the legal action may be preserved intact."); City of Morgantown v. Royal Insurance Co., 337 U.S. 254, 258 (1949) ("The Constitution guarantees to litigants in the federal courts the right to have their cases tried by juries, and Rule 38 of the Rules of Civil Procedure explicitly implements that guarantee. Denial of the right in a case where the demanding party is entitled to it is of course error.").

67 A number of Supreme Court decisions stem from the threshold assumption that the seventh amendment applies in federal courts. In Colgrove v. Battin, 413 U.S. 149 (1973), for example, the Court upheld a Montana district court's practice of empaneling six rather than twelve person juries in civil cases. To determine whether the Montana practice violated the seventh amendment, the Colgrove Court applied a loose version of the seventh amendment historical test, see note 71, concluding that the reduction in jury number from twelve to six did not offend the seventh amendment because the reduction did not alter the "substance" of the 1791 common law civil jury trial.

By going through this historical test, the Colgrove Court presumed the seventh amendment applied in federal court. If the seventh amendment did not necessarily apply in federal court, the Colgrove Court might have quickly dismissed the plaintiff's claim by arguing that the plaintiff waived his seventh amendment rights when he chose to appear before a federal six person jury rather than the standard twelve person jury provided by Montana's courts.

See also Whitehead v. Shattuck, 138 U.S. 146, 151 (1891); Hipp v. Babin, 60 U.S. 271, 278 (1856) (both indicating that there is a constitutional right to jury in federal court).

${ }^{68}$ See In re U.S. Financial Securities Litigation, 609 F.2d 411 (9th Cir. 1979) (court refused to recognize a complexity exception to civil jury right even though the jury would have to read over 100,000 pages and trial would take approximately two years); SRI Intern. v. Matsushita Elec. Corp. of America, 775 F.2d 1107, 1131 (Fed.Cir. 1985) (Markey and Newman joining in opinion and adding additional views) ("The district court, in announcing its decision to deny a jury trial and employ a bench trial, said 'these questions' could be resolved in that way 'more economically and expeditiously.' But whether judicial economy and expedition might be served is irrelevant. The Seventh Amendment contains no 'economy' exception.").

Some courts, however, have carved out a complexity exception to the seventh amendment based primarily on due process grounds. See, for example, In re Japanese Electronic Products Antitrust Litigation, 631 F.2d 1069, 1088 (3rd Cir. 1980) ("denials of jury trial on grounds of complexity should be confined to suits in which due process clearly requires a nonjury trial. . . . It is not enough that trial to the court would be preferable. The complexity of a suit must be so great that it renders the suit beyond the ability of a jury to decide by rational means with a reasonable understanding of the evidence and the applicable legal rules."); ILC Peripherals Leasing Corp. v. International Business Machines, 458 F.Supp. 423, 444-49 (N.D.Ca. 1978), aff'd on other grounds as Memorex Corp. v. International Business Machines, 636 F.2d 1188 (9th Cir. 1980); In re Boise Cascade Securities Litigation, 420 F.Supp. 99, 103-08 (W.D.Wash. 1976); Bernstein v. Universal Pictures, Inc. 79 F.R.D. 59 (S.D.N.Y. 1978). See generally Jeffrey Oakes, The Right to Strike the Jury Trial Demand in Complex Litigation, 34 U.Miami L.Rev. 243, 289 (1980). 
pervades the federal judiciary as an institution, Supreme Court and lower federal court opinions treat the federal civil jury trial right in appropriate cases as a given and neglect to explain the right's source or justify its continued existence. Therefore, although these opinions support the position that the federal courts must provide civil juries, they do not conclusively establish this right. The Constitution's text, however, demonstrates that federal civil litigants have the right to a jury trial. In addition, Congress itself has recognized this principle-if federal courts need not provide civil juries, then large chunks of the present statutory framework governing the relationship of state and federal courts would yield unconstitutional results. Finally, a system in which only state courts provide jury trials might unconstitutionally inhibit exercise of seventh amendment rights.

a. Textual Argument. Like the other liberties contained in the bill of rights, the seventh amendment did not apply to the states at the time it was ratified. ${ }^{69}$ If the amendment did not apply in state courts, the framers must have intended for the amendment to apply in federal courts.

A possible response to this argument might be that the framers intended the seventh amendment to serve as a fallback provision: the amendment would obligate federal courts to furnish jury trials in civil cases only if state courts failed to do so. The Constitution's limit on federal jurisdiction undercuts this reading of the seventh amendment, however. Because cases falling within federal jurisdiction comprise such a small subset of the cases falling within state courts' general jurisdiction, the federal courts may only provide civil juries to a small percentage of litigants denied juries by state courts. If the framers had intended the seventh amendment to safeguard against the denial of the jury trial right in general jurisdiction common law courts, then the framers would have made an exception to the limited federal jurisdiction in circumstances where the state courts refuse to honor the common law civil jury trial right.

More likely, and as the history surrounding the enactment of the seventh amendment bears out, the framers proposed the seventh amendment because they recognized the importance of the

69 Minn. \& St. Louis R.R. v. Bombolis, 241 U.S. 211, 217 (1916). Although the Court has held that other bill of rights' provisions bind state governments through the fourteenth amendment, the Court has not included the civil jury trial right in this category. See Walker v. Sauvinet, 92 U.S. 90, 92 (1875) (neither the privileges and immunities clause nor the due process clause makes the seventh amendment applicable to the states). 
civil jury trial right at common law and sought to incorporate that right into the federal system. The federalists agreed to include the seventh amendment in the bill of rights as a concession to the antifederalists, who had been clamoring for a new constitutional convention. The anti-federalists' motivation for seeking adoption of the seventh amendment indicates that the framers intended the seventh amendment to apply in federal courts. First, the anti-federalists feared that without the seventh amendment, British creditors might take advantage of federal alienage jurisdiction and sue American debtors before federal judges likely to be more sympathetic to the creditors than state court juries. Second, the anti-federalists sought to guarantee that American citizens could sue federal officials before juries. ${ }^{70}$

b. Rules governing the relationship between state and federal courts. Courts should read the seventh amendment as guaranteeing federal litigants the right to demand a civil jury for a second reason. Any other reading would seriously disrupt the existing body of jurisdictional and procedural rules that organize litigation in the federal and state courts.

(1) Choice of forum and removal. The seventh amendment guarantees civil jury trial in suits at "common law" and, under the Supreme Court's historical test, guarantees civil jury trial in claims grounded in federal statutes that codify causes of action recognized by the common law in 1791, the year of the seventh amendment's adoption. ${ }^{71}$ Under existing federal law, which binds state courts through the supremacy clause, a plaintiff has an absolute right to bring suit in federal court if the plaintiff can fit his or her cause of action within the statutory grant of federal jurisdiction. Similarly, a defendant may remove an action brought against him or her if the plaintiff originally could have brought suit in federal court. ${ }^{72}$ Because the jurisdictional grant frequently extends to both common law actions and actions based on statutes that codify the 1791 common law, the existing choice of forum and removal statutes would work an unconstitutional result in a system where only state courts provide civil juries. These statutes would allow one party, by insisting upon federal adjudication, to frustrate the other party's demand for a jury trial in a suit within the scope of the

${ }^{20}$ See generally Charles W. Wolfram, The Constitutional History of the Seventh Amendment, 57 Minn.L.Rev. at 673-705 (cited in note 62).

${ }^{71}$ See, for example, Colgrove, 413 U.S. at 155; Patton v. United States, 281 U.S. 276, ' 288 (1930).

${ }^{22}$ See 28 U.S.C. $\$ 1441(\mathrm{a})$. 
seventh amendment.73

Diversity jurisdiction ${ }^{74}$ represents the most obvious path by which common law claims reach federal court. If only state courts provide civil juries, one party might use diversity jurisdiction to prevent the other party's access to a jury in even the most paradigmatic common law suit. An Illinois citizen, for example, complaining that his Wisconsin neighbor's tree had fallen on his land and damaged his property, ${ }^{75}$ might bring a diversity action in federal court and thereby prevent the Wisconsin defendant from defending this suit before a jury. If the Illinois plaintiff sued the Wisconsin defendant in an Illinois state court, the Wisconsin defendant could remove the case to federal court and prevent the Illinois plaintiff from prosecuting his tort claim before a jury.

In a system where only state courts provide civil juries, the grant of federal jurisdiction in cases "arising under" federal law" would also create potential conflict with the seventh amendment. Since that statute extends federal jurisdiction to all cases arising under federal law, the statute by definition confers federal jurisdiction over statutory actions that codify 1791 common law rights. Arising under jurisdiction, therefore, in a system where only state courts provide civil juries, provides another mechanism by which one litigant might deny a second litigant's right to jury trial over a cause of action protected by the seventh amendment.

An injured railroad worker, for example, may sue his or her employer in federal court under the Federal Employers' Liability Act (FELA) for damages resulting from the employer's negligence. Prior to the FELA's enactment, the employee would have sued his employer for common law negligence; FELA preempts and modifies these common law actions (for example, FELA eliminates assumption of risk as a defense). ${ }^{77}$ Applying the Supreme Court's historical test, the railroad company defendant plainly has a sev-

73 A further problem would develop under the one exception to the normal removal rules. 28 U.S.C. $\$ 1441$ (b) provides that even if diversity exists between the parties, a defendant may not remove a suit if the plaintiff brings the suit in a state court of the defendant's home state. If only state courts provide civil jury trials, this provision allows a diversity plaintiff to decide, regardless of the defendant's wishes, whether trial should proceed before a judge in federal court or before a jury in a state court of the defendant's state. By discriminating in favor of plaintiffs, a system where only state courts provide civil juries not only offends the seventh amendment but also may violate the fourteenth amendment's equal protection clause. U.S.Const. amend. XIV, § 1.

74 28 U.S.C. \$ 1332.

7s See The Thorns Case, Y.B. Mich. 6 ed. 4, f. 7, pl. 18 (1466).

7828 U.S.C. $\$ 1331$.

77 U.S.C. $\S 53$. 
enth amendment right to a jury trial because the common law has long recognized negligence actions by an employee against his employer. But, in a system where only state courts provide civil jury trials, the plaintiff, by virtue of the federal arising under jurisdiction, might frustrate the defendant's seventh amendment right by suing the railroad in federal court. Conversely, if the employee had brought suit against the railroad in state court, the railroad might have used the removal laws, coupled with the arising under statute, to deny the plaintiff's seventh amendment right by forcing the plaintiff to litigate in federal court.

(2) Exclusive jurisdiction. If only state courts provided civil jury trials, then many statutes would be patently unconstitutional where they both codify 1791 common law actions (and therefore come within the seventh amendment's purview) and provide for exclusive federal jurisdiction. This suggests, then, that not recognizing a right to a civil jury trial in federal court will invalidate large chunks of Congress' remedial plan.

Federal copyright law, for example, preempts actions that copyright holders could bring at common law prior to the federal statute's enactment-for example, actions for unfair competition. ${ }^{78}$ According to the Supreme Court's historical test, litigants suing under the copyright statute or defending against actions brought under the statute have a seventh amendment right to a jury trial. If the federal system did not include jury trials, one could argue that the copyright statute as a whole is unconstitutional, because it forces litigants to argue 1791 common law causes of action in a forum which does not provide civil jury trials.

c. The possibility of an unconstitutional burden. Even if state courts did satisfy the seventh amendment guarantee and even if Congress could amend the framework governing the relationship between state and federal courts so that a system where only state courts provided jury trials would not directly offend the seventh amendment, such a bifurcated system still might be unconstitutional. Specifically, it would burden seventh amendment rights by discouraging litigants from asserting those rights if they wished to enter federal court.

"Arising under" federal jurisdiction was intended to shield federal law from local bias; diversity jurisdiction was intended to shield foreign litigants from local prejudice. ${ }^{79}$ In a system where

78 See generally Melville B. Nimmer, Copyright 251-52 (2d ed. 1979).

78 See Guaranty Trust Co. v. York, 326 U.S. 99, 111 (1945); Bank of United States v. Deveaux, 9 U.S. 61, 87 (1809). 
only state courts provided juries, a foreign litigant, a plaintiff seeking enforcement of a federal cause of action, or a defendant asserting a federal defense would have to balance his or her interest in an unprejudiced trial against his or her preference for a jury trial. If state courts satisfy the seventh amendment and federal courts refuse to provide civil juries, then the system systematically and unconstitutionally inhibits litigants from exercising their seventh amendment rights to jury trials. Accepting a similar argument, the Supreme Court in United States $v$. Jackson, ${ }^{\mathbf{8 0}}$ struck down part of the Federal Kidnapping Act" after finding that the Act "discouraged" litigants from demanding jury trials. The Kidnapping Act allowed a jury to impose the death penalty on a defendant the jury found guilty of kidnapping under certain conditions, but the statute set forth no procedure for imposing the death penalty if the defendant waived jury trial or plead guilty. Holding that the Act impermissibly burdened the exercise of the criminal defendant's sixth amendment right to a jury trial, Jackson argued that, "the evil in the federal statute is not that it necessarily coerces guilty pleas and jury waivers but simply that it needlessly encourages them."82

While the Court in Jackson may have been especially sensitive to a burden on the defendant's sixth amendment right because the death penalty was involved, one can infer from Jackson that if an institutional system discourages litigants from exercising their rights to jury trials, then the system is unconstitutional. The logic favoring recognition of "chilling effects" in general justifies this conclusion: if the Court did not accept claims based on inhibitions placed on the exercise of rights, individuals could not attack statutes or systems that frustrate the expression of constitutional rights through disincentives rather than direct deprivation. ${ }^{83}$

2. Imposing the Affirmative Obligation on the Government and, More Specifically, on Congress. If the seventh amendment applies to federal proceedings, does this amendment impose an obligation on government to provide civil juries and an obligation on Congress to appropriate the requisite funds? This subsection argues that the seventh amendment must impose these affirmative

so 390 U.S. 570 (1968).

118 U.S.C. § $1201(\mathrm{a})$.

82390 U.S. at 583 (emphasis in original).

ss See, for example, Dombrowski v. Pfister, 380 U.S. 479, 487 (1965) ("The chilling effect upon the exercise of First Amendment rights may derive from the fact of the prosecution, unaffected by the prospects of its success or failure."). 
obligations, because otherwise the amendment lacks any substance.

Some courts and commentators have argued that the Constitution does not grant positive rights, meaning that the Constitution does not obligate the government to take any action or to provide any servicès. Rather, according to these commentators, the Constitution serves solely as a negative charter, prohibiting the government from acting in conflict with the principles embodied in the Constitution. ${ }^{84}$

Many constitutional provisions are negatively phrased. It makes sense in these instances to argue that the Constitution only restricts government action. Professor Currie has written, for example, that "the due process clause is phrased as a prohibition, not an affirmative command: 'nor shall any State' is the equivalent of 'a State shall not.' Moreover, what the states are forbidden to do is to 'deprive' people of certain things, and depriving suggests aggressive state activity, not mere failure to help." ${ }^{85}$ As a textual matter, the seventh amendment differs from provisions like the due process clause because the seventh amendment is not negatively phrased. By requiring that "the right of trial by jury shall be preserved," the amendment implies government action: the government must continue to act as it did prior to the bill of rights' enactment.

More importantly, if the seventh amendment does not impose an affirmative obligation on government to provide litigants with civil jury trials, then the amendment is meaningless. With provisions like the due process clause, the positive and negative rights distinction works. If, for example, the due process clause does not grant an affirmative right to assistance from the government for the exercise of a right, the clause still has some content because alternative means of engaging in the protected activity exist. The Court's dicta in Harris v. McRae illustrates this point:

Although the liberty protected by the Due Process Clause affords protection against unwarranted government interference with freedom of choice in the context of certain personal decisions, it does not confer an entitlement to such funds as may be necessary to realize all the advantages of that freedom. . . .

84 See Judge Posner's dicta in Jackson v. City of Joliet, 715 F.2d 1200, 1203 (7th Cir. 1983)("The Constitution is a charter of negative rather than positive liberties. . . The men who wrote the Bill of Rights were not concerned that government might do too little for the people but that it might do too much to them."). See generally, David P. Currie, Positive and Negative Constitutional Rights, 53 U.Chi.L.Rev. 864 (1986).

${ }^{8 s}$ Currie, 53 U.Chi.L.Rev. at 865. 
It cannot be that because government may not prohibit the use of contraceptives ... or prevent parents from sending their child to a private school, . . . government, therefore, has an affirmative constitutional obligation to ensure that all persons have the financial resources to obtain contraceptives or to send their children to private schools. To translate the limitation on governmental power implicit in the Due Process Clause into an affirmative funding obligation would require Congress to subsidize the medically necessary abortion of an indigent woman even if Congress had not enacted a medicaid program to subsidize other medically necessary services. ${ }^{86}$

This logic does not apply to the seventh amendment. Because dispute resolution in the courts is under government's exclusive control, the Constitution's command that government shall preserve the right of trial by jury is useless if government does not also have a concomitant duty to provide litigants with civil juries.

In other, more subtle cases, the Court has held that constitutional provisions mandate governmental assistance where the rights embodied in the provisions would be meaningless without governmental intervention. In Bronson $v$. Kinzie, ${ }^{87}$ for example, "the Court held that a state could not destroy a mortgagee's foreclosure right by denying him an effective remedy." the Court interpreted the contracts clause to require the state government to protect the mortgagee's claim against the mortgagor. If the state could withdraw remedies, then the state could impair contractual obligations: "no one, we presume, would say that there is any substantial difference between a retrospective law declaring a particular contract or class of contracts to be abrogated and void, and one which took away all remedy to enforce them or encumbered it with conditions that rendered it useless or impractible to pursue it." 88

Similarly, in Truax $v$. Corrigan," the Court "held that a state could not constitutionally forbid injunctions against picketing by striking workers." As one explanation for its holding, the Court reasoned that "by withdrawing the injunctive remedy, the state

s6 448 U.S. 297, 318 (1980)(upholding the Hyde Amendment's restrictions on public funding for abortions).

${ }^{87} 42$ U.S. 311,320 (1843). This comment's discussion of Truax and Bronson paraphrases Professor Currie's treatment of the two cases, 53 U.Chi.L.Rev. at 875.

${ }^{83}$ Id. at 875.

89 42 U.S. at 317. Quoted in Currie, 53 U.Chi.L.Rev. at 875 n.66.

90257 U.S. 312 (1921). 
had deprived the employer of property without due process of law." Here, as in Bronson, the Court imposed an affirmative governmental duty because the Court recognized that "[p]roperty, like contract, entails a right against third parties that is worthless without government help."'1

Courts should apply the logic of Bronson and Truax to the seventh amendment context. These holdings illustrate the need for recognition of an affirmative constitutional duty on Congress to provide funds for civil jury trials because, like the right to property and contract, the right to a civil jury trial is meaningless without government assistance.

\section{When Delay Becomes Denial: The Search for Constitutional Standards}

Part II argued that the seventh amendment imposes an affirmative duty on government to provide civil jury trials. Congress, however, is more likely to decrease funds available for civil juries than to stop funding civil juries altogether. At what point does an appropriation that merely slows the rate of civil jury trials work an unconstitutional result? Part III of this comment argues that the "unconstitutional conditions" doctrine provides a standard that federal courts can use when deciding whether to treat a civil jury trial delay as a civil jury trial denial.

\section{A. There is No Constitutional Right to a Speedy Civil Trial}

The Justice Department argued in both Armster and Hobson that the budget shortfall and the resulting suspension of civil jury trials did not violate any constitutional right because, although the Constitution guarantees a criminal defendant the right to a speedy trial, a civil litigant does not enjoy a similar right. The Armster court explicitly rejected this argument, holding that because the Supreme Court has emphasized the importance of jury trials, litigants have a constitutional right to a speedy civil trial: "Specifically, we conclude that the seventh amendment right to a civil jury trial is violated when, because of such a suspension, an individual is not afforded, for any significant period of time, a jury trial he would otherwise receive." ${ }^{\prime 2}$ The court also held that the period of over three months challenged in Armster constituted "far more

91 Currie, 53 U.Chi.L.Rev. at 876.

${ }_{82} 792$ F.2d at 1430 . 
than a significant period."9s

The Armster court's creation of a speedy civil jury trial right lacks textual and precedential support and should not be used as a basis for challenging congressional underfunding of civil juries. First, Armster runs contrary to the text of the Constitution since the sixth amendment, the only section of the Constitution which refers to "a speedy and public trial," guarantees this right only in criminal cases. And, the text of the seventh amendment, although vesting civil litigants with the right to a jury trial, does not provide civil litigants with a right to a speedy trial. ${ }^{.8}$ Second, although various Supreme Court decisions have emphasized the importance of the civil jury system, the Court never has recognized the right to a speedy civil jury trial. The Court surely has had an opportunity to create such a right, because delay in the federal civil system is a widespread and well known phenomenon.98

Finally, the reasons articulated by the Supreme Court in its enforcement of the sixth amendment right to a speedy criminal trial do not support recognition of a similar right in the civil context. The Supreme Court has justified the speedy jury trial right not by pointing to events that might occur if either a criminal or a civil jury trial was delayed, such as ordinary inconvenience to the parties, but by focusing on injustices that are unique to criminal cases. ${ }^{97}$

If the speedy trial right for criminal defendants did not exist, the government could violate an arrestee's due process rights by forcing him or her to serve a substantial sentence before trial. Justice Brennan in Dickey $v$. Florida argued that the speedy trial clause "is intended to spare an accused those penalties and disabilities-incompatible with the presumption of innocence-that may spring from delay in the criminal process."98 The fear that litigants will be deprived of their liberty prior to a jury trial does not arise in the civil context where, except in rare cases such as deportation

9s Id.

* U.S.Const. amend. VI.

os U.S.Const. amend. VII.

96 See Richard A. Posner, The Federal Courts: Crisis and Reform 96 (1985) (after filing, federal litigants in 1983 had to wait, on average, 19 months until disposition; in 1960, federal litigants had to wait, on average, 17.8 months).

${ }^{97}$ Smith v. Hooey, 393 U.S. 374, 377-78 (1969). See Pollard v. United States, 352 U.S. 354, 361-62 (1957); Beavers v. Haubert, 198 U.S. 77, 86 (1905); and cases cited in notes 98100.

s3 398 U.S. 30, 41 (1970)(Brennan concurring). See also United States v. Ewell, 383 U.S. 116, 120 (1966) (speedy trial right "is an important safeguard to prevent undue and oppressive incarceration prior to trial"). 
and juvenile proceedings, the government does not infringe upon the civil litigant's freedom either before, during, or after trial.

Because the government stigmatizes the criminal defendant by accusing him or her of a crime, the Supreme Court has also argued that the right to a speedy criminal trial is necessary because it ensures that the defendant does not experience unnecessary anxiety. In Klopfer $v$. North Carolina, for example, the Court insisted that the speedy trial right is necessary in the criminal context because criminal prosecution may subject a person to "public scorn and deprive him of employment, and almost certainly will force curtailment of his speech, associations and participation in unpopular causes."98 The fear of stigmatization that motivates application of the speedy jury trial right in criminal cases carries over into the civil context in a reduced number of cases and to a far lesser degree. A party accused of breaching a contract, for example, suffers significantly less social embarassment than a criminal defendant.

Finally, the Court has argued that the speedy trial right "serves the public interest by penalizing official abuse of the criminal process and discouraging official unlawfulness."100 Deterrence of official misconduct is, in general, not a relevant consideration in the civil context where the government does not characteristically instigate the suit and is often not directly effected by the suit's outcome.

Although delay in proceedings may inconvenience civil litigants, civil delay clearly is less harmful than criminal delay. The case for extending the speedy trial right to the civil context therefore is unconvincing.

B. The Unconstitutional Conditions Doctrine Provides a Standard for Evaluating the Constitutionality of Jury Trial Delays

Assuming that there is no constitutional right to a speedy civil jury trial, do courts have any standard by which they can judge the constitutionality of a civil jury trial delay? ${ }^{101}$ This section argues that, faced with a situation where, because of underfunding, a civil jury trial empaneling is significantly delayed but not completely denied, courts should apply the "unconstitutional conditions" doctrine and treat the delay as an effective deprivation of the litigant's seventh amendment right. The unconstitutional conditions doc-

98 386 U.S. 213, 222 (1967).

${ }^{100}$ Dickey, 398 U.S. at 43 (Brennan concurring).

101 If a court did not possess standards for evaluating the constitutionality of a civil jury trial delay than the issue would arguably be a political question. See note 48 . 
trine "holds that government may not condition the receipt of its benefits upon the nonassertion of constitutional rights even if receipt of such benefits is in all other respects a 'mere privilege." "102 The theory underlying the doctrine is that government should not be able to accomplish indirectly, through the conditioning of government-granted benefits, that which express constitutional provisions forbid it to do directly. ${ }^{103}$ The government cannot, for example, condition the granting of a government job on the government employee's agreement not to exercise her right to an abortion.

The unconstitutional conditions doctrine should apply in the case where the government delays civil jury trials due to underfunding. In this instance, the government is conditioning the granting of a benefit, timely access to the federal courts, on the litigant's waiver of his or her seventh amendment right. ${ }^{104}$ If a civil litigant, for example, has to wait six years for a jury trial but only a year for a bench trial, a court should find that the government has denied the litigant his or her seventh amendment right because the government has effectively coerced the litigant to waive a civil jury trial through the conditioning of a benefit. ${ }^{105}$

The Supreme Court established the unconstitutional conditions doctrine in Frost Trucking Co. v. Railroad Commission, ${ }^{106}$ where the Court held that the federal government could not condition the use of the nation's highways on a private carrier's agreement to convert to a public carrier. Since Frost, two versions of the unconstitutional conditions doctrine have emerged. The strong version says that the state may never condition the granting of a benefit on a person's agreement not to exercise a constitutional

${ }^{102}$ Laurence H. Tribe, American Constitutional Law, \& $10-8$ at 510 (1978).

${ }^{103}$ William W. Van Alstyne, The Demise of the Right-Privilege Distinction in Constitutional Law, 81 Harv.L.Rev. 1439, 1445-46 (1968).

104 This argument assumes that when faced with underfunding for civil juries, courts will decide to continue granting timely bench trials rather than needlessly delaying bench trials so that the wait for bench trials equals the wait for jury trials.

${ }^{103}$ In certain circumstances, the argument might be made that litigants have a due process right of access to federal courts. In these cases, then, it may be misleading to refer to court access as a "benefit" conferred by the government. Nonetheless, for purposes of the unconstitutional conditions analysis, there is no difference between a case where the government conditions a granting of a benefit on waiver of a constitutional right and a case where the government conditions a constitutional right on the waiver of another constitutional right. See United States v. Pizarro, 717 F.2d 336, 348 (7th Cir. 1983) (unconstitutional conditions doctrine "precludes the government from coercing the waiver of a constitutional right . . . by conditioning the exercise of one fundamental right on the waiver of another."); Peter Westen, Incredible Dilemmas: Conditioning One Constitutional Right on the Forfeiture of Another, 66 Iowa L.Rev. 741, 745-58 (1981).

${ }^{108} 271$ U.S. 583 (1926). 
right. A slightly weaker version provides that government may only condition the granting of a benefit on a waiver of a constitutional right when government has a compelling interest that justifies the condition. ${ }^{107}$

The Court's opinion in Garrity $v$. New Jersey, ${ }^{108}$ illustrates its application of the doctrine's strong version. In Garrity, the Court held that New Jersey could not threaten to fire police officers suspected of wrongdoing who refused to testify during an investigation of their actions. Rejecting the contention that the condition was justifiable if New Jersey could demonstrate a compelling interest in requiring the police officer's testimony, the Court stated that coercion was "inherent in this scheme of questioning ... [w] [were the choice is 'between the rock and the whirlpool,' duress is inherent in deciding to 'waive' one or the other."109

In other cases, however, the Court has considered arguments that the state had a compelling reason to condition the granting of a benefit on the waiver of a constitutional right. In Sherbert $v$. Verner ${ }^{110}$ for example, the Court invalidated a South Carolina law that withheld unemployment benefits from persons who made themselves less attractive to potential employers by refusing to work on Saturdays for religious reasons. The Court, however, implied that the South Carolina law would have passed constitutional scrutiny if South Carolina had presented a compelling state interest justifying the condition: before announcing its holding, the Court distinguished Sherbert from an earlier case by arguing that the state regulation at issue in Sherbert did not further a substantial, legitimate state interest. ${ }^{111}$

Similarly, in Branti v. Finkel, ${ }^{112}$ the Court held that the first amendment prevented the state from discharging an assistant public defender solely because of his political beliefs. The Court indicated, however, that in certain circumstances a compelling state interest might justify this type of firing: "If the First Amendment protects a public employee from discharge solely based on what he has said, it must also protect him from discharge based on what he believes. Under this line of analysis, unless the government can demonstrate 'an overriding interest,' . . . 'of vital importance,' . . .

${ }^{107}$ Peter Westen, The Rueful Rhetoric of "Rights," 33 UCLA L.Rev. 977, 979-80, 980 n.2-3 (1986).

${ }^{108} 385$ U.S. 493 (1967).

109 Id. at $497-98$.

110374 U.S. 398 (1963).

111 Id. at 408-09, distinguishing Sherbert from Braunfeld v. Brown, 366 U.S. 599 (1961).

112445 U.S. 507 (1980). 
requiring that a person's private beliefs conform to those of the hiring authority, his beliefs cannot be the sole basis for depriving him of continued public employment."113

Supreme Court precedent indicates, then, that if the court reviewing a civil jury empaneling delay applies the strong version of the unconstitutional conditions doctrine, the court need not evaluate the federal government's interests in underfunding for civil juries. A substantial delay in jury trials relative to bench trials will itself be unconstitutional. A court might, however, apply the weaker version of the doctrine; in this circumstance, should the court find that the government has a compelling interest justifying the time lag between bench and jury trials?

The government's major interest in underfunding of civil juries is the saving of money. In the unconstitutional conditions context, courts cannot accept the principle that these savings justify the government's conditioning of a benefit on the waiver of a constitutional right. As an analytic matter, accepting this argument would allow the government to condition the granting of any benefit $X$ on the waiver of any constitutional right $Y$ where the exercise of right $\mathrm{Y}$ requires either directly or indirectly an expenditure of public funds. Under this reasoning, the government could, for example, condition the granting of federal jobs on prospective employees' agreement not to vote because paying voting inspectors and setting up voting booths costs the government money. Or, to take an equally extreme example, the government could condition the payment of social security benefits on recipients' agreement not to object to federal agents' unconstitutional searches and seizures because compliance with the fourth amendment costs the government money both in officer training and in wasted investigations. In other contexts, the Court has denied that saving money is a compelling state interest justifying the government's abrogation of constitutional rights. ${ }^{114}$

Under either line of the unconstitutional conditions doctrine,

113 Id. at $515-16$.

114 See, for example, Shapiro v. Thompson, 394 U.S. 618 (1969) (Court rejected fiscal integrity as a compelling governmental interest that could overcome a burden imposed on the right to travel by a state welfare program's residency requirement).

Even if saving money by itself is a compelling state interest, the government must use the least restrictive means to pursue this interest when denying litigants their seventh amendment rights. See, for example, Sherbert, 374 U.S. at 407 ("[E]ven if the possibility of spurious claims did threaten to dilute the fund and disrupt the scheduling of work, it would plainly be incumbent upon the appellees to demonstrate that no alternative forms of regulation would combat such abuses without infringing First Amendment rights."). 
the government deprives a litigant of his or her seventh amendment right when it coerces the litigant to "waive" this right by allowing the litigant timely access to court only after a jury trial waiver. How should courts apply this doctrine to varying civil jury empaneling delays?

In light of Frost Trucking, the crucial inquiry must be whether the government has coerced the litigant to waive his or her seventh amendment right by structuring the litigant's choices so that the litigant feels compelled to accept an earlier bench trial. $^{115}$ By incorporating the coercion standard, the unconstitutional conditions doctrine avoids the problem that might result if any disparity between the scheduling of a bench trial and a jury trial created a seventh amendment cause of action: a brief delay will not coerce the defendant to surrender his or her seventh amendment rights. Presumably for example, a court would find constitutional a time differential no longer than the present difference between the wait for a civil jury trial and the wait for a bench trial, since all seem to assume that the present system does not compel litigants in federal court to accept bench rather than jury trials. ${ }^{116}$

\section{CoNCLusion}

Rather than responding to congressional underappropriation for civil juries by recognizing a self-executing appropriation power in the judiciary, courts must accept the limitations placed on their power by the Constitution. The interdependence of the branches, however, implies not only that the government's structure places limitations on the judiciary's power, but also that the structure places limits on the power of the political branches.

This comment argues that the seventh amendment limits Congress' appropriation power by imposing upon Congress an affirmative obligation to finance appropriate civil jury trials in federal court. Faced with situations where litigants are denied civil jury trials because of underfunding, federal courts should remedy these constitutional violations by empaneling civil juries and sending the bill to Congress.

115 Frost, 271 U.S. at 583.

${ }^{116}$ For statistics on present delays see note 96. 